\title{
Ways of Social Tension Easing in the Coal- Mining Region
}

\author{
Elvira Zabneva ${ }^{1, *}$, Elena Nagrelli $^{2}$, and Julia Kuznetsova ${ }^{3}$ \\ Novokuznetsk branch T.F. Gorbachev Kuzbass State Technical University, 654000 Novokuznetsk, \\ Russian Federation
}

\begin{abstract}
The objective: to consider the peculiarities of social tension occurrence in the coal-mining region. Methods: the research is based on the awareness of the fact that social tension is a mass adaptation syndrome that reflects the degree of different population categories physiological, psychophysiological and social-psychological adaptation (or maladaptation) to chronic frustration, hardships (drop in living standards and social changes).Social tension is addressed through the lens of both population categories: the population living on the territory of a coalmining region but not employed in coal-mining industry as well as population directly employed in coal-mining industry. Results: the factors influencing the degree of social tension of the population living in a coalmining region and directly employed in coal-mining industry have been released. Conclusion: the ways of social tension in coal-mining region easingbased on integrated research data have been offered. It has been determined that sustainable development of a coal-mining region must be connected with the following interrelated aspects: ecosystem preservation, satisfaction of human needsas well as life quality satisfaction together with efficient resources distribution and others. It has been proved that maximum involvement of thecitizens in social and political life plays the discrete role in the process of social tension easing in a coal-mining region.
\end{abstract}

\section{Introduction}

Nowadays coal is an important source of energy, its share amounts to $40 \%$ in electricpower production and $30 \%$ in primary energy production. During the last decade coal consumption has grown twice whereas the consumption of oil and atomic power growth is less than $15 \%$. [1].

Russian coal-mining industry has a number of advantages, such as, the existence of considerable mineral wealth (the world's second biggest), ample opportunities to access the world market, variety of coal products, appliance of innovations [8]. However, these advantages do not eliminate major deficiencies of mining industry, one of which is high level of social tension in coal-mining regions.

It should be mentioned that social tension is part and parcel of social life. It is a specific state of social conscience and behavior, specific situation of reality perception and

${ }^{*}$ Corresponding author: zabnevailvira@mail.ru 
evaluation. As a rule, such state is caused by a conflict and accompanies it and the scales and intensity of social tensions directly depend on the scale of the conflict itself.

\section{Methods}

The work is based on the awareness that social tension is a mass adaptation syndrome that reflects the degree of physiological, psychophysiological and social-psychological adaptation (or maladaptation) of different population categories to chronic frustration, hardships (drop in living standards and social changes). The social tension is manifested in dramatic rise of dissatisfaction, distrust to the authorities, conflict in society, anxiety, business and mental depression, and feverish demand, decline of the demographic situation, as well as in compensatory reactions (aggression, enemiessearching, hoping against hope), stress-productiveness of relationships. These phenomena are determined by the economic climate, the authority efficiency, media influence and the opposition and criminal networks [13].

Social tension capturesboth: the population living on the territory of a coal-mining region butnot employed in mining industry as well as the population employed in coalmining industry.

The following factors exercise determining influence upon the degreeof social tension: first of all, low opportunities to get a job in a coal-mining region apart from direct employment in mining industry as well as the unfavorable ecological state of the territory that is located nearby coal mines and open-pits that influences physical and psychicalstatus of population.

\section{The Results}

Coal-mining industry causes serious damage to the environment of the coal-mining region. The areas of cultivation, forests, wetlands, are often allocated for minesand open-pits construction that has harmful influence on water quality in rivers as well as on subterranean waters [12]. Joint impact of these factors causes population dissatisfaction and mass migration from the coal-mining region that has a dramatically negative impact on sustainable development of local community [11].

A variety of negative factors connected primarily with fear to lose job as well as high level of hazard to life and health influence the degree of social tension among people directly employed in coal-mining industry. Despite the increase of coal extraction volume in Russia, increase of productivity (over the last decade the increase almost tripled), the number of people employed in this branch of industry decreased from 225.4 thousand people in 2007 to 139 thousand people in 2017, the number of coal-mining enterprises dwindled to the level of 161 units in 2017 (from 228 units in 2010).

The people employed in coal-mining industry are constantly emotionally and physically strung up. That undoubtedly influences the quality of safety compliance during mining works. Hazards to mine-workers' life are widespread: beginning from dust explosion, ending with inundation and common mechanical mistakes. From S. Balbir's point of view the hazards can be formed into following groups: human-factor and mistakes insecurity of operational procedures in mines, insufficient safety of mining equipment, low quality of mining-works safety electronic system [2]. According to him, the human factor which includes non-compliance of safety rules and of manufacturing procedures as well as poor workplace culture top the mining accidents causeslist. Studying labour relations in mining industry scientists also emphasize such negative manifestations of the staff tensionas accidents, unexcused absence, strikes, staff turnover [10]. 
The table 1 presents the dependence of accidents, fatalities number and specific injury rate onthe volume of coal extraction from 2008 to 2017 in the Russian Federation.

Table 1. Dependence of number of accidents, fatalities and specific injury rate on volume of coalextraction from 2008 to 2017 in the Russian Federation.

\begin{tabular}{|c|c|c|c|c|c|c|c|c|c|c|}
\hline \multirow{2}{*}{ Year } & \multicolumn{3}{|c|}{$\begin{array}{c}\text { Coal extraction, } \\
\text { mIn. t. }\end{array}$} & \multicolumn{4}{c|}{ Accidents } & \multicolumn{3}{c|}{ Specific fatality rate, people. / } \\
\cline { 2 - 11 } & total & $\begin{array}{c}\text { UG } \\
\text { M }\end{array}$ & OPM & total & $\begin{array}{c}\text { UG } \\
\text { M }\end{array}$ & OPM & $\begin{array}{c}\text { PP+S } \\
\text { PF }\end{array}$ & total & UGM & OPM \\
\hline 2008 & 319.5 & 105.3 & 214.2 & 12 & 9 & 1 & 2 & 0.16 & 0.389 & 0.037 \\
\hline 2009 & 301.8 & 108.4 & 193.4 & 9 & 8 & - & 1 & 0.15 & 0.332 & 0.047 \\
\hline 2010 & 323.2 & 102.7 & 220.5 & 22 & 17 & 1 & 4 & 0.41 & 1.188 & 0.054 \\
\hline 2011 & 337.4 & 101.0 & 234.4 & 13 & 9 & 1 & 3 & 0.13 & 0.327 & 0.043 \\
\hline 2012 & 355.2 & 112.9 & 242.3 & 16 & 11 & 2 & 3 & 0.10 & 0.247 & 0.021 \\
\hline 2013 & 352.0 & 101.0 & 251.0 & 11 & 11 & 0 & 0 & 0.17 & 0.554 & 0.016 \\
\hline 2014 & 358.2 & 105.3 & 252.9 & 8 & 7 & 1 & 0 & 0.07 & 0.17 & 0.019 \\
\hline 2015 & 373.4 & 103.7 & 269.7 & 8 & 6 & 2 & 0 & 0.05 & 0.1 & 0.02 \\
\hline 2016 & 385.7 & 104.6 & 281.1 & 8 & 7 & 0 & 1 & 0.14 & 0.5 & 0.007 \\
\hline 2017 & 408.9 & 104.5 & 304.4 & 3 & 3 & 0 & 0 & 0.04 & 0.11 & 0.016 \\
\hline
\end{tabular}

Notes: UGM - underground mining, OPM - open-pit mining, PP + SPF - processing plants and surface production facilities.

Table 2. Dynamics of accidents and fatality injuries number at Russiancoal-mining enterprises in 2016-2017, units.

\begin{tabular}{|l|c|c|c|c|}
\hline \multirow{2}{*}{ Kind of accident and fatality } & \multicolumn{2}{c|}{ Accident } & \multicolumn{2}{c|}{ Fatality injuries } \\
\cline { 5 - 6 } & & $\mathbf{2 0 1 6}$ & $\mathbf{2 0 1 7}$ \\
\cline { 2 - 3 } & $\mathbf{2 0 1 6}$ & $\mathbf{2 0 1 7}$ & & \\
\hline $\begin{array}{l}\text { Explosion (combustion, inflammation) of gas and coal } \\
\text { dust }\end{array}$ & $4 /-/-$ & - & $36 /-/-$ & - \\
\hline Fire & $-/-/ 1$ & - & - & - \\
\hline Coal-mine bounce & - & - & - & - \\
\hline Coal, rock, gasoutburst & - & $1 /-/-$ & - & $1 /-/-$ \\
\hline Decayofbuildings, structures, technical equipment & - & - & - & - \\
\hline Transport & - & - & $3 /-/-$ & $3 / 1 /-$ \\
\hline Electric current & - & - & - & $-/ 2 /-$ \\
\hline Machines and mechanisms impact & - & - & $7 /-/-$ & $5 / 1 / 1$ \\
\hline Falls & - & - & $-/ 1 /-$ & - \\
\hline Mineworkinginundation, waterirruption & $1 /-/-$ & $-/-/ 1$ & - & $1 /-/-$ \\
\hline Rock mass fall, support fall & $1 /-/-$ & $1 /-/-$ & $7 /-/-$ & $2 / 1 /-$ \\
\hline Intoxications and choke & - & - & - & - \\
\hline Other kinds of accidents and injuries & $1 /-/-$ & - & $1 / 1 /-$ & - \\
\hline TOTAL & $7 /-/ 1$ & $2 /-/ 1$ & $54 / 2 /-$ & $12 / 5 / 1$ \\
\hline
\end{tabular}

Notes: UGM/OPM/PP+SPF

If to compare the data with the dynamics of coal extraction, it becomes clear that the specific rate of fatal injuries in 2016 is equal to 0.14 of a human-being per one million tons of raw material. If to compare these indicators with the global data, it becomes clear that 
the following countries have higher indicators: China (0.25) and Ukraine (1.194). In the following countries the indicator is lower: RSA (0.035), Australia (0.03) and the USA (0.011).

Never the less, over the years 2016-2017 the number of accidents in underground mining jobs came significantlydown ( 3.5 times), the cases of fatality injuries were 4.5 times reduced. However, the number of fatalities rose among the staff of open-pits, processing plants as well asofsurface production facilities.

Nowadays there has formed a spacious approach to the problem of social tension reduction in coal-mining region in the context of its development sustainability improving. In foreign countries the research works concerning industrial safety, perfection of industrial environment parameters control occupies the leading position. First of all, research works dedicated to methods and tools of hazards identification, risks evaluation and data analysis are emphasized [7]. In such a manner,Cheng Jianwei, analyzing the reasons and modes of explosions in underground coal-mines, points out the necessity of underground gas explosion risks methodology and the possible scenarios of their mitigating determination [5]. The author proves the strong need of explosion risk modeling and the obtained data implementation into practice, as that will allow the coal-mine operator implementing meaningful actions in proper time for the purpose of mining works and the staff safetyoptimization.

The research concerning improvement of miners' working conditions due to innovations appliance are considered to be a peculiar cluster among the ways of working conditions perfecting. First of all, they present cyclic technologies, robotic application and technology of coal advanced refining implementation and others [4]. It has been proved that they wield major influence on the quality of working conditions of the coal-mining enterprises staff.

As part of the staff social protection measures foreign authors emphasize not so much satisfaction of their social demands during their working career as miners'supporting after their work activitiestermination. Thus, LimT.W., Shimazaki.N., GodoY., Lim. Y. examine the peculiarities of dismissed miners' so-called «reabsorption» in the spheres of service and industry. The process of gentrification of coal-mining regions is studied on the basis of the following criteria: the origin of the territory and of social history as well as the threepronged factor «continuity- discontinuity and cooperation- opposition» influence [9]. The emphasis is put on such measures as priority current job placements, professional retraining, assistance in business undertaking.

Domestic scientific prospects of coal-mining industry sustainable development are often connected with «technical-raw material» directions of work, which are the following: production potential development, new coal deposits development; assertiveness of trading positions on the international market; improvement of technical and technological development; workplace safety andstaff quality improving. Social protection of coal enterprises staff and improvement of working conditions are also within the research area of Russian scientists.

Taking into consideration the current situation in this segment of industry we should speak about the improvement of social-economic development of coal-mining region and the people's employed in mining industry life quality from a perspective of human assets. The question is in the awareness of interrelation between social, ecological and economic problems as well as in taking into account a variety of interests and needs of different population groups and the territory and organizing cooperation that steps over the bounds of a specific enterprise [14]. So the sustainable development of coal-mining region should be connected with such interrelated aspects as the following:

1) ecosystem preservation that forms the basis and the premise of the society life quality;

2) meetinghuman needs and quality life satisfaction together with efficient resource distribution; 
3) meetingall kinds of social needs of the society, assistance in development of cultural expressions diversity, assurance of social resources equal availability.

Russian coal-mining region has based on specific activitiespotentialfor attractinginvestments and improving the performance of mining enterprises. However, the realized profit, except for a small portion that is invested in the industry development, goes beyond the regionfor the most part. Unfortunately, the socio-economic and political solutions taking into account the population well-being, ecological sustainability, needs of economic development of regions and citiesare minimized. Herewith, the existing experience shows that the process of the territory long-term development can be efficient only in case if:

1) not only the mining enterprises are supported but also the local entrepreneurs are assisted, small-business are developed;

2) constructive dialogue with the local population is realized;

3) structural reorganization of territory economy is managed competently;

4) circular economy is supported;

5) thesocial issues connected with population employed in this branch of industry and struggle against growing inequalityare managed.

Maximum population involvement into social and political life plays a pivotal role in the process of easing tension among the population living in a coal-mining region. Sincea considerable amount of unfavourable factors together with high dependence of socioeconomical state of the society on the financial state of the local economic mainstay influence the life activity of thepopulation living in a mining region, growth of civic engagement in its diverse forms may become,on the one hand, a tool of local community tension relief, and on the other hand, a powerful detonating mechanism. So a skillful concentration of social energy and its directing to the issue of public management functioning is needed. There should be created necessary conditions for public-private partnership, their formal observation; and what is the most important,the partnership must be accepted by its participants as a kind of a reference point in the real process of socioeconomic policy development and realization.

The following three priority areas of civic initiative development are the most important:

1) productivity, workplaces, economic diversification, that is, the policy that gives an impulse to coal-mining industry, allows supporting the productivity, cementing links concerning the basic kind of activity and supporting the economy diversification and transition period efforts;

2) the population life quality and well-being, that is, the policy, oriented to life quality improvement and that takes into account the inclusive growth of socio-economic wellbeing, that affects regions and cities with a high degree of dependence on the mining industry;

3) subnationalgovernance and fiscal mechanisms: they concern complex relationships between national and subnational governments, mining industry and parties concerned with the issues of economic development and well-being.

Ecological well-being of a coal-mining region must become the specific direction of civic initiatives development, that is: awareness-raising, social supervising the consequences of mineral resources extraction, business and the authority bringing to corporate responsibility. It is important to involve all levels of the state and municipal governance in managerial decision framing, as well as to involve a corporate level of efficient environmental protection policy formulation, ecological culture and socially responsible behavior shaping. In our view, the improvement of ecological well-being of the coal region should be based on "green" experience of Western companies. Their activity has shown that environment care is an effective tool of their competitive ability 
improvement and the development of different modes of their professionals' and civil society collaborative work is one of the most effective tools of improving the population life quality.

\section{Conclusion}

The research showed that the degree of social tension wields major influence on the sustainable development of modern coal -mining region. What is more, the structure of tension varies considerably according to the source of its outbreak. Nowadays, a new stage of civil society development, characterized by growing opportunities for personality selfrealization, makes it possible to consider civil initiatives as an effective tool of the population living in the coal-mining regionsocial tension easing. Herewith, the most important directions of civic initiatives development are the following: the population life quality, subnational governance and fiscal finances, as well as maintaining a high quality of staff ' working environment.

\section{References}

1. Africa Regional Report on the Sustainable Development Goals, Summary by the Economic Commission for Africa. (Economic Commission for Africa, Johannesburg, 2015)

2. S. Balbir-Dhillon, Mine Safety (Springer-Verlag, London, 2009)

3. A. Ishkanian, E. Gyulkhandanyan, S. Manusyan, A. Manusyan, Civil society, development and environmental activism in Armenia (City Print House Ltd Co.,London, 2013)

4. Y. Guangxi, L. Shuiqing, Proceedings of the 8th International Symposium on Coal Combustion (Springer Science+Business Media, Singapore, 2016)

5. J. Cheng, Explosions in Underground Coal Mines (Springer International Publishing, Berlin, 2018)

6. J. Maiti, K. Pradip, Ray Industrial Safety Management (Springer, Singapore, 2018)

7. F. Redmill, T. Anderson, Components of System Safety (Springer-Verlag, London, 2002)

8. L. Schernikau, Economics of the International Coal Trade (Springer International Publishing, London, 2016)

9. T. W. Shimazaki, N. Godo, Y. Lim, Coal Mining Communities and Gentrification in Japan (Palgrave Macmillan, London, 2019)

10. B. J. McCormick, Industrial Relations in the Coal Industry. (Palgrave Macmillan, London, 1979)

11. Q. Zhou, Advan. Mater. Res., 11:634-638, 3423 (2013)

12. M.G. Qian, Coal Sci. \&Tech. Mag., 4, 1 (2003)

13. R. Rob, P. Zemsky, RAND Journ. of Econ., 33, 243 (2003)

14. A. Thierstein, M. Walser, 39th Congress of the European Regional Science Association: "Regional Cohesion and Competitiveness in 21st Century Europe», (ERSA, Dublin, 1999)

15. OECD Mining Regions and Cities: Better policies for better lives. Proposal and Options to Participate (Palgrave Macmillan, London, 2018) 